\title{
On Writing
}

\section{Kuangming Wu}

Philosophy Department, University of Wisconsin-Oshkosh, Oshkosh, USA

Email: kmwu2002@yahoo.com

How to cite this paper: $\mathrm{Wu}, \mathrm{K}$. M. (2018). On Writing. Sociology Mind, 8, 304-319. https://doi.org/10.4236/sm.2018.84020

Received: July 27, 2018

Accepted: October 8, 2018

Published: October 11, 2018

Copyright $\odot 2018$ by author and Scientific Research Publishing Inc. This work is licensed under the Creative Commons Attribution International License (CC BY 4.0).

http://creativecommons.org/licenses/by/4.0/

\section{Open Access}

\begin{abstract}
We regularly write to shape daily engagement accordingly. We freely shape writing that shapes us, and through us to shape our lifeworld. Writing creates things continually via our writing that creates us. Writing is itself most fragile and ephemeral, only to turn incorruptible and invincible, world without end.
\end{abstract}

\section{Keywords}

Life, Death, Joy, Pain, Kids, Creation, Music

\section{Writing}

Human beings alone write. Animals are also social but only human beings are aware of being social themselves. Human self-awareness is then expressed in writing and as writing. Writing is distinctively human to express distinctive humanity. Oral tradition tends to change and peter out. Oral tradition so unreliable must thus be written down, to stay assured through time as legends and mythologies. Silent words that stand written turn humanity incorruptible and immortal so loud. Thus, writing deserves looking into in this paper that is itself writing. Writing alone conveys writing assuredly.

Writing is peculiar, because it reflects itself. Writing reflects the self to the self. Human self can look at what the self has written as its object and refines it and develops it. Self-reflection grows itself into a new self. Such is what writing does. Writing reflectively re-shapes itself to refine it, in the mutuality of self to self. Self-reflection is self-mutuality. Writing is self-reflectivity that begins such mutuality, and then develops from mutuality of self with self to self with other selves, on to self with other things.

Self-reflective mutuality develops from mutuality between self and self to self with other selves, and then self with the other things. Self-thing mutuality amounts to our science knowledge of Mother Nature. All such various sorts of mutuality are enabled by our assiduous writing-down of all our discoveries. 
Furthermore, self-reflective mutuality develops into mutuality with posterity in later time, called "history", thanks to writing all things down that happen.

Writing as the self reflected in the others is a mutual activity itself. Such self-reflection constantly stares at our point blank in the face. It is thus that writing facilitates learning from our own self-reflection through time. We learn from history. History is self-knowledge of humanity. Even Auschwitz so horrible that we cannot look at it in the face can be written down for us all to learn, so as never to repeat the similar horror against fellow human beings.

Especially the victims of Auschwitz are in an especially unique and appropriate position to stop perpetrating this horror, because they of all persons have personally undergone the horrors. Sadly, however, the Israelis themselves are still learning from this horrible lesson to stop the horror once and for all, as they are still inflicting precisely the similar brutalities on their weaker neighbors today. When would they finally see the light reflected from their own past horrors? Only history can tell, much later.

All this while, writing remains the sober art of stern warning never to be mocked without courting disasters. Writing is the serious reflection of humanity, never existing in animal world. All too sadly, however, Japan is avidly erasing its own record of its own past so brutal so tragic and bloody, and so essential and constitutive of itself. Writing is self-reflective so scary and so inevitable. It hurts to erase such writing, and it hurts to re-read it. Writing hurts, erased or read.

The ancient China as the Middle Kingdom has a dubious honor of 50 odd centuries of repetitions of bloody consecutive despotic dynasties, on continuous records written down till today. China today still is a nauseatingly familiar dynasty of despotic tyranny on the point to touch off another popular revolution ready for another bloody overthrow. Why do we never get tired of bloody repetitions of brutal atrocities? Can we make a change of it for a change, for a totally novel beginning? No one loves bloody pain, and we all tirelessly repeat it, as we tirelessly write on such brutal repetitions-called "history" so tiresomely and painfully familiar, and nothing to be proud of at all.

Even in the USA that is supposedly the first world experiment of amicable togetherness, symbolized by the warm Statue of Liberty, so many crowds of American Indians are silently bearing the blunt of xenophobia, homophobia, racism, misogyny, discriminations, together with the silent majority of common folks, for centuries on end. The greatest crook Donald Trump has stolen presidency by colluding with a foreign nation manipulating the election. His act is the high treason of the worst kind.

You name it, Trump has it. Money laundering to brutalize employees under him, while continually committing adulteries of all sorts, Trump is all over around to please KKK and neo-Nazis, all of whom absolutely support him. Still, the Trump regime is just a chilly tiny tip of chilly huge iceberg under ugly USA. Conscientious journalism is currently busy writing the history of USA so horrendously ugly, so many years continually groaning under systematic brutalities economic and political and otherwise. And, can you imagine? USA is the "best" 
among all current nations in the world. Writing is exposing all this not pretty and never decent.

Still, writing in this way remains typically human, shamefully above animals. Human writing tells us human beings that we must prostrate before innocent animals to learn from them, as we human beings faithfully write about humanity and the animal kingdom. To write as human describes humanity to prescribe us into authentic humanity. Such writing is indeed our human imperative to learn to shape up human.

To write expresses humanity. To describe and write-down all this never expresses pride of being human, however. On the contrary, such writing is our urgent human command to learn from what we have written all over, on pain of perishing as human for failing to learn from our writing-as-human. We keep writing as human. We perish as human for failing to learn from our own writing as human.

\section{Death}

What! Blank; mad; open; sighs.

It is how life goes and undergoes death. Two sisters fell in love with a boy. On leaving them, the boy promised to return, and left them-and died. The sisters pined after him into trees in breeze. Love can embrace death in breeze, this sad way. It is a good question as to whether love is more comprehensive than death or death is. Something like this about death must now be unpacked, for death is too important to leave alone. We must elucidate death at least partially, as follows.

We are aware that life continues to die away each moment, and we only have a view from life (that we are) of such process of dying. All this while, no life knows what death actually is. We try to confront death to see what death is straightly, but we cannot. This is because death is nothing and nowhere, and "nothing" cannot be confronted, of course. And yet, strangely, death is so immediately "alive" as to make things vanish, as things are engulfed in deathly silence. Death is not an innocent "nothing" in this strange way, being so far away and so intimately close, somewhat as follows.

Someone dies. Thin surface scratched, there oozes pain unbearable, raging with anger and sorrow. Fury and grief mix, so empty. Death is sheer unbearable pain of life. Slowly, vast "ahead" recedes far. Weary and sluggish, one step guides its next, each as senseless as ones before and after, all going nowhere somewhere, all unknown. All this while, things are moving unawares, only to vanish as they move on unknown, to vanish and away-in death.

"Ahead" is not ahead, receding does not recede, and yet nothing stays put. Such is death totally unknown. Death is too empty to stay put. Death is pain, sheer pain all too much to stay, and nothing stays anyway, no matter what, alive or dead. Tylenol is taken to soothe unbearable pain of staying not-staying. Tylenol of life keeps vainly soothing death moving not-moving. All this goes on in sheer pain of living on as death strikes. 
Death is sheer pain of life, but what is such pain? For what is such pain? No answer comes from nowhere. Ignorance here-in death-is not bliss at all. "Nothing is bliss" is death. Stool is pushed, empty. It is part of death, but death has no part. Death is blank pain, not even stool. It is cloudy in high noon quite eerie. No single bird is here chirping life. Death has no bird, all silent beyond silence and no-silence. Things keep vanishing soundless, and they are quite painful continuing to vanish. Death is here.

Things are sinking but not sinking down; they just keep sinking nowhere. We do not know what to do with such death that is nothing and cannot be dealt with. Still, death is clearly pain all over, quite numbing. Death is pain of nothing that is not even a blank pit. Death is pain unknown. Death is "unknown as pain." Death is pain of vanishing and pain in vanishing. Death is vanishing-as-pain, and receding-as-pain. Vanity of vanity, death is all-vanity bottomless. Things are engulfed in death unknown and in pain. Death is nothing not-known, and is so powerful a dark shadow of nothing, albeit so powerful. Death is the "black hole" personal and cosmic.

Time slides away into no-place, while pain shrouds deep and spreads wide. Such is death. "Can you not win? Join them", whispers our common sense. But, while constantly conquered, we cannot even join death, as death is a nothing, and we cannot join "nothing". Being conquered and cannot join, we are just helplessly engulfed in death the power of nothing unseen, unheard-of, and untouchable, and we continually vanish away defeated.

Death is a strange power to let things continually vanishing alive-in the strange vanity of death that just defeats all things. Death is alive and does not discriminate. "Alive" here in death is strangely unknown to all things. "Vanity" of death is simply senseless as death is senselessly empty. Ignorance parades itself proudly as death, as nothing that is powerless power.

Death continually recedes nowhere, with Tylenol as vain palliative. Death continually sucks things away nowhere. Not even anger and not even grief are here now. Sorrow is also sucked away nowhere called "death". Vain and useless, pain pervades far and wide, for nothing. Such is death all otiose and almighty. Defeated and defective, death all-powerful spreads far and wide, for nothing. Death totters, and death stumbles, all for nothing. Death as nothing just hurts, not knowing what hurt is, not knowing what the hurt is for. Even pain hurting is for nothing as death.

In the end, death whispers, "It's OK to be silly and sad. It's OK to constipate. It's Ok to hang in midair." Death is such strange knowledge calm and serene. Writing has kept all this as our knowledge, however ugly, unseemly, and unable to shake off. Writing is intimate with knowledge. Knowledge includes even death. Knowledge deserves looking into, somewhat as follows.

\section{Knowledge}

Things appear and jostle in, to make an impact on us. Such impact composes 
"knowledge" to enable us to live on. Knowledge is quite difficult and mysterious. Confucius is one of very few persons in the world who is most widely and constantly read, recited, quoted, and discussed, and we still sadly say, "Confucius read, Confucius unknown"! He remains aloof and far.

In the same way, "China" can also be quoted extensively and remains missed. In contrast, while without a single quotation from China, China can be penetrated thoroughly to elucidate its soul, as my On Chinese Body Thinking does $(\mathrm{Wu}, 1997)$. Now here is another dramatic example of how mysterious knowledge is, also quite concretely drawn from my China studies.

I spent years of intensive soul-reading of the Chuang Tzu, and wrote two books on him (Wu, 1982; 1990). And then, I began reading Confucius and surprised to find Chuang Tzu smiling there without appearing as "Chuang Tzu". All my writings on various diverse themes, in many books and articles, mention no "Chuang Tzu," who yet is clearly present in them. Confucius and all other themes that I have written manifest Chuang Tzu who is physically absent. Does absence here indicate knowledge or no knowledge?

Confucius was in turn present while I was studying Chuang Tzu. It is literally true in fact that "Within Four Seas, all people are brethren," as a disciple of Confucius intoned (12/5). People as brethren interpenetrate, timely spatially. "Knowing one" amounts to knowing the other. Now, is knowledge specific, uniquely specific about a particular matter, or is it dispersed and so amounting to no-knowledge?

Other concrete examples abound on the difficulty of knowledge. Incredibly, married spouses can live together and embrace habitually for many decades until their many sleep-sheets turn threadbare one by one, and these spouses can still continue to remain unknown to each other-until exposed on page by objective writing about them. Without intimate penetration back and forth, the spouses remain lonely and empty, each living alone. Do these couples know or do not know?

God knows how many married couples of this sort there are in our lifeworld, even while these couples produce children and spend decades raising them. "Spouses joined, spouses unknown," many brute facts through time and space report to us. Such tragedy abounds in the lifeworld, quite as "Confucius recited, Confucius unknown," as faithfully revealed by written history. Knowledge is difficult indeed.

Let us go a step further, into the self. Knowledge of the self is awesomely mysterious. Descartes missed deliberating on "I feel me, therefore I am as I am," and so his "I think, therefore I am" ended in his mistaken separations of body from mind, as separation of the extended from the not-extended. In the Cartesian Cogito, cognitive dualism of all sorts, quite separative, stubborn stays.

Separative dualism kills the original vital unity of the selfhood of any thing. Lack of internally heartfelt knowledge of self-identity harvests a scattered lack in vital spontaneous unity of each existence. Such harvest is quite existentially se- 
rious. However difficult it is to attain knowledge such as this, in this basic level, lack of knowledge kills existence itself.

Thus, "I think, there I am" ironically fumbles into a loss of the "I am," and such self-loss kills all thinking founded on the self. And so, "I think, therefore I lose myself," reports Descartes' Cogito that has no self even to begin thinking in the first place. Descartes committed the most serious, subjective transcendental fallacy as Hume did, who still honestly reported his failure to find the self in "a bundle of perceptions" that he only found in his objective search for the subjective self. Descartes was so lost (self-loss) that he was unaware of being lost in self-loss, to turn into a cognitive zombie.

Thus the self is indispensable in all situations. Job and Jeremiah cursed their own birthdays under unbearable pain, but it remains unknown as to whether they were aware of their own "self" that was in such pain. Socrates famously urged us all to "know thyself," but did he of all persons know his own self? His dialogue with his beloved Crito divulged that he was so ignorant of himself as to fail to learn from Crito's common sense. Socrates was so trapped in his insane logic as to wander away from Crito's sane sense so commonly shared among us.

Crito's common sense was that the self changes with the change of its life-situations, "it was one time, this is one time," as wisely declared by Mencius 2B13. Court verdict of death penalty was "one time." The later realization, the verdict was unjust and obedience of unjust verdict is unjust, is a different "one time." Socrates' unrealistic cognitive consistency cost his life by neglecting such valid and life-critical situation-change, and he was not even aware of his fatal mistake.

Socrates made this mortal and silly mistake that followed the insane historic misjudgment. The Athenian verdict totally unjust was one of the two notorious misjudgments in world history, another one being Pilate's on Jesus. The Athenian verdict was previous to this fatal tragic mistake of Socrates who obeyed the unjust verdict to his death. This is our hindsight that is far better than Socrates'. This hindsight is importantly enabled by writings of the Apology and the Crito.

Socrates dramatically shows "self lived, self not known" in silly empty consistency so lethal. Beware of proudly following such unrealistic reasoning! Never follow reasoning. Follow "my self" instead! What we essentially need to be alive is to stubbornly pursue our "self knowledge." Socrates tragically failed to pursue his self-knowledge, despite his own wise injunction to all of us through the ages to know our self first of all and above all.

The self stays as the single, unique and central pivot through Job, Jeremiah, Descartes, and Hume, as well as Socrates. No self, no reason or even humanity itself. It is the self that penetrates reasoning to guide reasoning to life. And mind you. All this is presented by writing. No indispensable writing, no such indispensable injunction to "know thyself." Writing is the "words" that stand "incorruptible" through all history.

Let us go back to "knowledge." If knowledge is so difficult, does our lifeworld 
have any knowledge real and priceless? Amazingly, such heartfelt authentic knowledge exists everywhere in an ordinary Mom hugging her usual baby. As "far and yet near is girl-boy relation," so "unique and yet common is Mom-baby love." Mom knows her baby simply because he is she herself.

Her baby is blood of her blood, bones of her bones, and every tissue of her baby is totally hers. Mom simply knows her baby inside out, and every twitch of the baby's muscle twitches her own muscle, exactly as she knows herself and behaves herself, because her baby is her own self now and her tomorrow. Mom and her baby are one in two, two as one. Mom lugs her baby as Mom lugs herself, as her baby tells her how to lug herself. Mom immediately hears him crying faintly and far, while Mom heartily enjoys laughter and talks aloud among friends, self-forgotten.

The baby is Mom's final destination, and her own destiny final and total. Her baby is her total and absolute pride into which she invests her total life day in and day out. Isn't all this carnal knowledge? Isn't it soulful knowledge? Such knowledge is more intimate than knowledge of bodily sex out of which her baby came. Her baby is now the "lord" who majestically joins her to her husband who is promoted by his baby to the "father" of their baby. Fatherhood is creator of novel precious existence, their future now, so plump and fresh.

They the parents unconditionally obey their baby's command of heartfelt needs, bodily, educational, and the future. Their responsibilities are joyously joined to their assiduous pride and pleasure unspeakable and enthralling. Their baby is their pride, joys, and responsibilities. The fruit of Mom's womb is the unconditional Lord of Mom's and Dad's joy and duties. Their baby guides their lives into authentic humanity. All violence is tamed into their baby-joys, and no one can resist such joys. No one is even willing to oppose such joys! Baby-joys are absolutely invincible.

As Mom and Dad hug their priceless baby in turn, they feel unconditionally sure of the total certitude of this baby-joy heartfelt; they feel it in their bodies and their souls. Their shared love of their baby solidifies their nuptial affection forever, in ultimacy so heavenly. Divorce is chased out of their love of their baby shared intimately, in body, in mind, and in soul.

Nothing is more heartfelt, authentic, and total than the "knowledge" smiling at the shared baby here between his parents. No deprivation of any sort can be imagined in description-writing-down-of this authentic knowledge that is sheer joy of unbearably proud parents. All pain turns bearable to bear away, enabling all joys of assiduous acts of responsibilities to come in to prevail all around the baby. Such knowledge is paradise.

Now, amazingly, personal knowledge such as above would then spread in time. We today know better the medieval genius Mr. Ssu Tung-p'o than Mr. Ssu himself or his contemporary friends; it is "easier to know a dead man than a living one," begins his sympathetic biographer, Lin Yutang (Lin, 1948). Such knowledge of posterity writes into "history" to deepen and certify knowledge. 
History writes and records today the knowledge we now have of what Hitler had in mind and in his heart of hearts about the Jews he hated. No one knew it then, much less Hitler himself. All history today reveals to us now that Hitler was one eighth Jewish himself. So, being partly Jewish instinctively deepens his anti-Semitism. "So near increases so far," says history.

Written history today gives us such uncanny knowledge of the ancients such as Ssu Tung-po and Hitler. Knowledge about them we today know but they did not know themselves. Such recorded history makes no mistakes because any mistakes found written in history are continually written again and corrected further. Self-correcting history makes no mistake, and historical discoveries and corrections are made possible by writing down in history itself that writes on things that happened. Writing is pivotal.

The baby grows up to come to know intimately about his dearly beloved parents. Likewise, we the posterity today know our revered ancients even better than they know themselves, through their history left us in writing. I now know heartfelt why my Dad died young of toxic goiter; it was out of being broken hearted, tragically shown scrawled all over ancient poems of bloody love that he kept. I now shed tears daily for my dearest Dad whom I fervently adore as the greatest hero in the whole world.

We have thus shown that such knowledge in history and through history is at once enormously difficult and intimately immediate, in space and in time. What is amazing is that such extraordinary knowledge far and intimate is actually just our routine ongoing of every common day, and it is nothing esoteric. Knowledge is our wonder of all wonders. No less wonderful is that the knowledge must be conveyed in ephemeral words, and words written down are anything but ephemeral.

What is incorruptible comes from the persistent fact through history that our bits of knowledge keep being written down and read. An example comes to mind. "Our life is a white colt passing through a door-crack," so sighed Chuang Tzu (22/39) twenty-five centuries ago. This sentence about how short our life has been read repeatedly for 25 centuries. This sentence has lasted for that long, and will last much longer and further beyond today. Words so ephemeral, once written down, stand incorruptible forever.

Our ephemeral knowledge so incorruptible makes valid our self. And then our validated self comes to softly remove our curses of our birthdays. Far and yet so near is how girl and boy relate, because "far and near" is our knowledge of life and of the self. And such girl-boy relation brings forth our self and our life to last on and on. Likewise, written knowledge composes our days far and intimate, ephemeral and incorruptible.

In other words, writing is wonder of daily wonders. Distance in knowledge composes intimate knowledge and still remains distant, only then to dissolve itself in comprehensive knowledge. Distance establishes intimate knowledge, as distance turns knowledge intimately close at heart. Now knowledge is authentic 
knowledge, both far and near, both mysterious and intimate, as it is both known and unknown.

In all this, the distance of knowledge is kept up while the distance is melt away nowhere, Knowledge is such mystery to compose the mysterious self in daily living, so uncanny and so ordinary each moment. We now have such knowledge of the common that is now realized as awesome bottomless and yet humdrum common. Knowledge, knowledge, all is known, while nothing is known, all starkly present as brute fact, confronting us in daily ongoing. We know knowledge unknown.

Knowledge is alive in such a strange way. Our knowledge of some things leads us to many more things unknown and our knowledge surceases, only to resurrect itself into history-knowledge that extends to the ancients and to the posterity. Again, as far and near, being difficult and intimate, knowledge pervades all over in space and in time. Knowledge is uncanny this way. We are aghast in knowledge unknown, all of which reduces us to silence quite wordless, as constantly reflected in written history.

In this context, Chinese calligraphy appears quite uncanny and significant. No wonder I am madly in love with it. Here in ancient beautiful-writing of calligraphy, each stroke whispers an eternal biography silently aloud. Gloating over these strokes each single day initiates us into an intimate knowledge of life without anyone alien, much less a single enemy. Calligraphy that is sheer beauty has no opponent anywhere.

Calligraphy announces that all various peoples are brethren within Four Seas. And in fact, all writings in all world are actually "calligraphy" that is the beautiful-writing as autobiographies of all persons everywhere all the time. Sincere writings turn beautiful to bring us all together, mutually known as intimate biography. Lin Yutang wrote on the medieval Mr. Ssu the genius, as so many people wrote on Mr. Abraham Lincoln the all-time favorite President.

\section{Creation}

Writing is "creative writing." Writing creates. "What writing is" is what writing does; "is" is "does" in writing. All this means that writing is not an object to see but an impact to create. Writing exists not as a static object but as an activity ever creative of objects, static or moving. Writing does not-exist but creates existence. Writing is nowhere but creates everywhere. In writing, creation happens spontaneously. Writing creates. Without writing, nothing exists.

And then, writing-creation is creation not (just) out of nothing but creation out of before-nothing. What does it mean? To begin, writing creates its own tool the writer, what is "before-nothing" in writing. Are we depressed, decrepit, cynical, complaining, and feeling lousy all over? Write it all out, and it will write itself out of existence. Writing therapy is part of writing self-creation, of writing out of before-nothing. Writing creates its tool the writer before writing creates things. 
In addition, writing creates out of before-nothing by revising what has been written before. Revising re-envisions, seeing-again. Re-vising refines what was written before. Refinement is a new creation of things novel. Writing is creatio continuo, creation continuing endless out of before-nothing, continuing to write itself out spanking new. Writing continues to write out writing, writing anew writing a-better. Writing is self-creation continual in novelty and into novelty.

All these writing activities parallel traditional theism. Writing is divine. In the beginning, writing-logos writes out creation continuous. Our lifeworld is continually being written out, as things negative are being written out of existence. As a result, every single day is a new creation out of writing before-nothing. Writing renews the world into New Heaven and New Earth. The world is whatever is written out alive, spanking new, ever happening afresh.

In all such creation continuous, writing is the total comprehensive Lord over all, all over as Creator of all things and their entire lifeworld. And the wonder of it all is that writing even writes out its own tool of writing the writer, we ourselves. Even we can write anytime to create our own world. We are divine creators, thanks to our writing as divine creator that even creates us as its tool to write things out!

And then our written world can naturally blend in with our other fellow writers and their other worlds. The history of many such worlds then writes out to come about. All of us then hum along together the hymns of praises of our written worlds in our written creations. Writing-as-lord is voluptuously social. Sociality is writing creation continual, continually spreading through space and continuing in time.

Writing is creation ever spanking new, calm and vibrant, unique and universal together, alive with soft impacts that create worded wordless, in silence aloud. In writing, nothing creates out of before-nothing to proliferate the lifeworld-whatever all this means - that sings the world all over, world without end. Writing creates, ever. Writing is almighty calligraphy that beautifully-writes out the world alive afresh. And the world is now such beautiful-writing, such calligraphy concrete, vast, enthralling, and irresistible. Almighty writing is ever enticing, ever creative, and ever beautiful, world without end.

"But why does writing have to continue to write, to continue to create at all? Continuation is an enigma of writing that shows itself as having no 'once for all." A good question you raised, pal. Writing creation must keep going because things alive keep vanishing away. All lives will die away; death is the indubitable fact of all things. Death is ubiquitous in grass and among squirrels, even barking dogs and kids shouting and chasing dogs.

Even the longest lived of all lives, those lush trees, eventually dry up and vanish into soil, and the soil must go from dust to different sort of dust. Therefore, life must be replenished at a regular rate. Creation of things alive requires continual re-creation. Fortunately, such re-creation is joy of recreation alive. Things enjoy being born and reborn, as all of us can never get over new babies. What we 
have noticed is that such joy of re-creation is amazingly performed by our feeble writing that comes up and goes away soon, exactly as any and all life does. Writing alive creates things alive, and vanishes as things die. And so, writing that creates must continue to create again, and then must create all over again, continually.

In addition, re-creation is renewal so refreshing. The parents give birth to new babies—no baby is old baby-who are all fresh, just joyously "sprouting" as new bulbs about to blossom. No one can resist such plump new lives cooing and wooing, suckling at Mom's breast all too eager and hungry, all too jumping alive so tender so soft. Continual dying all-hardened implicates continuing re-births all-plump. Resurrection is part of re-deaths.

Creation continual is required by repeated deaths and amazingly sired by death continual. The funerals conducted by "lower levels" of life such as worms amount to preparation of future births and rebirths so fresh, tender, and vibrant. Funerals are birthday-parties. Few people realize this amazing fact, and so few funerals are lusty celebration of new birthdays. Writing officiates these birthday-parties.

"Does writing do officiate funeral-deaths as well?" Well, to think of it-thanks for reminding - writing does craft epitaphs, which are decorated after death and before birth. Death-orations are before-nothing of life, and before-nothing of death. Writing as Lord of creation is by the same token the Lord of death that prepares the eruption of life. Memorial services are pervaded with written orations of lives gloriously lived precious and previous. No written certificate, then no death is certified. By the same token, birth-certificates fill the church records of families that compose Family Bibles.

It is thus that writing as creation continual implicates writing as epitaphs to death continuous. Life implicates death as its end, thereby death as its beginning. Life is as comprehensive as death is, as both death and life implicate one another. Writing presides over them both. Writing is thus the undisputed Lord of death in life, and of life out of death. The "and" here is an awesome connective that embraces all things alive in death, dying in order to live again. "I am resurrection and life," says writing that writes death. Claiming writing as the Lord claims writing pervasive and creative of both death and life of all things without exception. Writing creates after all, no matter what.

\section{Vision}

Now let us dig things deeper. Writing as creation is made possible by the miracle of writing that renders audible booming sense visible. Writing is the audible made visible. Even a silly doggerel, "Do you love me or do you not? You have told me but I forgot," sings out alive and happy, vividly and visibly, when written down on paper and written out for us to read. The jumping sense of sheer "alive" is fully manifested by writing these silly lines down. Dramas of living are written by Shakespeare into a boom-box of unending thrills and delight. 
Visible boom-box of writing captures invisible sense spoken audibly. Now senses alive are tangibly ready to shape and re-shape in any way that readers deem appropriate. "Shaping continual" makes for creation unceasing. Creation of the lifeworld is rendered actual by writing that makes things visible. Thus, the miracle of world-creation is actualized by the writing-miracle of turning anything invisible visible.

This miracle of writing, so important, so world-critical, can never be repeatedly rehearsed enough or too often. We see at least five aspects of this writing-miracle: one, words vanish, once spoken, two, writing turns speech visible, three, writing can be revised, four, writing is incorruptible, and five, writing creates. These five aspects compose writing as a sheer miracle quite personal and vastly cosmic. These five aspects amply deserve to look into, one by one.

One, words vanish, once spoken: Spoken words vanish away in thin air. Merely uttered speech is hollow "sound and fury, signifying nothing," and these Shakespeare's words are themselves sheer spoken fury utterly empty of meaning. Speaking is empty. Sometimes, speaking is not simple or innocent. Love so intense can overflow into hate a hundredfold, and shout out to vanish away. Even love all-important can shout away into fury of nothing, vanishing without a trace.

Words vanish as soon as they are spoken, even while words are being spoken. By the same token, their meaning lasts for quite a short time. Oral tradition is notoriously unreliable. Even ear-witnesses mutually differ and clash, and soon do not remember much anymore. Spoken words continue to vanish as "sound and fury, signifying nothing," as empty boom invisible, entirely meaningless and senseless.

Two, writing turns speech visible: Amazingly, writing renders audible boom so hollow visible, in a tangible way. Now the boom comes out raw and stark whenever writing is opened and read. Miraculously, writing turns all vanishing speeches visible right here and now, being ready anytime to present again what has happened raw booming, brute and factual.

Writing is a boom-box preserved, ready at each moment to explode into the drama of booming presence of sheer happening, spoken and otherwise. "Turning what is just audible and vanishing into something tangibly visible" involves preservation of what has boomed, as landmines silently lying underfoot, waiting at any moment to explode into raw and stark presence of brute factual actuality.

"Turning visible the audible boom so ephemeral" amounts to turning such unreliable boom into a ready explosion of resurgence of brute presence, of sheer dramatic actuality. "Turning hollow boom visible" stabilizes its hollow unreliability into assured existence, and readies its explosion into the raw original presence of actuality any time, as soon as what is visibly written is read and appreciated as such.

Three, writing can be revised: Now that things that have happened are now rendered visible, their written records can now be handled concretely. Their writing can be read to readily revise. Revision re-envisions. Revision looks-again 
repeatedly at what has been written down. Looking-again facilitates shaping and re-shaping, to refine what has been written. Rendering things visible solidifies their written record so as to revise and refine it, clearer and more assured if not more valid and more plausible.

A Yale professor William Christian once claimed that revision is where writing is at. Revision is the authentic soul of writing. We totally agree and add this point. It is writing itself that enables solid continual revisions to continual refinements of any writing. And it is writing that revises writing, because it is writing that stabilizes writing to solidify writing, and solidifying enable revisions of writing and its refinement to improve on it. Without writing solidification of writing, it is impossible to revise and refine any writing whatever.

Four, writing is incorruptible: Revisions and refinements are of course part and parcel of writing process that is writing itself. Such writing process cannot end, always taken over by writers continually arising from tomorrows oncoming. This amazing fact is telling us that writing is incorruptible. Being continually revised and refined, writing turns incorruptible and quite eternal.

Now, is not this fact a sheer amazement? Writing is one thing most fragile, uncertain, and ephemeral, and can be burned freely without restriction, as the Beginning Emperor of Ch'in actually tried. Amazingly, however, his dynasty lasted only fifty years, and writings have been continuing to flourish and proliferate more and more for centuries since those barbaric days, till today and far beyond today.

Can you imagine this surprising fact? Let us take a concrete example. A casual sentence casually mumbled 25 centuries ago, "Human life is a white colt passing through a door-crack" (said Chuang Tzu 22/39) has often been read till today, and will be read far beyond today till later days, and there is no end in sight. Actually, fragile and ephemeral writing continues to last longer than all human achievements recorded in history put together, as history itself is a writing left us since of old, and history itself has no end.

Five, writing creates: Incredible writing so incorruptible is itself quite alive. While we regularly shape writing, writing constantly turns around to shape us ourselves. History is writing on the past, and we take past history as our indubitable teacher-history does not tell a lie, we affirm confidently-to learn how to live and to behave as truly human. Grand historian Ssu-ma Ch'ien calmly judged that dictator Hsiang Yü perished because of his failure to learn from the ancients (Si, 2008) (not because of lack of stamina, or fated by heaven as Hsiang claimed).

Further extended, we realize that shaping us is part of incorruptible writing that continues to shape, in fact create anew, the entire cosmos. George Berkeley said that to be is to be perceived. We on our part must add this (to his initiating statement), that after being perceived, to be has to be written out, to stand-out existing, ek-histemi. Perception must write out to stand-out existing.

Being without writing out is as good as being without being perceived, to wit, 
no being. All this holds because perceiving turns things into objects, and "turning into objects" establishes existence. Writing accomplishes perceiving to objectify, without destroying perceiving that tends to empty booming, in need of being solidified by writing. Writing bundles up perception to solidify perception into existence.

Now, looking back, we have been through an unusual trek. Simple writing stabilizes unreliable boom of spoken words into visibly enabling revisions and refinements, so much so as to make writing incorruptible. Such incorruptible writing then turns around to shape us into humanity, and then on to create the lifeworld. All this stunning accomplishment is no less amazing than the miracle of writing. The miracle simply begins at writing stuff down, to write it out into existence. Writing is the miracle of creation continuing; such writing-creation is incorruptible.

\section{Act of Music}

Importantly, writing is not an object but an act of writing. Interestingly, this act writes out a thing, a situation, or an act, and while these matters appear, their act of writing itself disappears. The reader is referred to the matters alone that are written out, forgetting writing itself responsible for the appearance of all these written matters. The plump baby wows people, while his mother is hidden invisible, supporting him from behind to sustain his very survival plump and fresh.

Music must be performed afresh to sing out alive, but we come only to listen to music singing, not to performers performing. Music is performed to appear as music alive afresh, in which its performers must disappear. When the performers intrusively appear, the music is destroyed into performers. Writing writes music. As soon as writing intrudes into what is written, both writing and the written are destroyed. We have neither the writing nor the written. Writing intruding destroys writing.

Thus, the skill of writing consists in how ingeniously it constantly disappears itself inside its written matters it writes out. These matters then naturally evince their act of production called "writing." Writing is a hidden god without whom nothing exists. Music sings music; music sings no performer. Likewise, writing presents matters written; writing does not write out writing act.

Again, writing is thus a hidden god of writing. Good performers make good music in which performers vanish, and we its hearers say this music is performed well. Likewise, the music of writing where writing is hidden performs good music of writing singing, and the readers say these matters are written well; here, writing act hidden, nowhere to be seen, this writing appears as written well.

Teachers come to show us how to distribute our weight equally on the bow and the violin. Many books tell us how to spell our sentences decently in grammar and in proper syntax. We practice and practice, until we come naturally to breathe our violin of writing, and our writing comes to sing forth our fabulous songs of living. Singing in our life and singing our life, we continue to sing life in 
our writing that sings the whole cosmos, resounding in all harmonies of incomparable music, all quite incorruptible.

Our writing takes off each single day to sing on and on. Our writing is our music alive, chanting the universe, world without end. Writing chants the Joy of music beyond all sorrows. Writing-music sings away all life-negativities. Autistic people love to sing. Writing sings lustily to open out centripetal autism. What remains is all joy continuous, day and night. Such writing joys have no end, simply because joy does not corrupt away. Joy is written out incorruptible, ever.

\section{Conclusion}

All in all, this paper has discovered writing to be extremely versatile. Writing is intensely personal, because all writings are personally written, and yet such private writing is meant for all to share, because sharing is the purpose of writing out things in the first place. Such writing is freely shaped up and down, while such shaped writing continues to shape us its writers and its readers as it is written out. Moreover, nothing is more ephemeral than writing, ready anytime to be tossed into a waste-basket, and yet all this while, such casually written stuff can last incorruptible for countless centuries.

All writing is freely created, often far out of this world so strange, so as to create things hitherto never existed, on and on. Writing on and on then composes history that we freely shape as we live on, only to turn around to demand us to learn from the ancient past we have written down-study history is our life-obligation, we claim-in order to live human and to behave as truly human. And such list of writing-amazements continues on and on. Writing is simply incredible, quite stunning.

Now, here is the crunch to top it all. Among these stunning surprises of writing, there appears the wonder of all writing wonders. It is this. Being a mere instrument of writing, it is still we ourselves who must initiate such incredibly powerful writing so versatile. We the writers are the unique initiation of writing-stunts personal and cosmic, private and social, frivolous and creative. The writing-amazements begin at our writing-hand, however arbitrary, however whimsical, as actually our writing is often so frivolous.

Once initiated by us, the incorruptible writing would then take over and continues to correct itself into proper creation of things continuous. All this while, we the writers are the intimate participants of creation continuous. We the writers however flippant are in good hand of writing to initiate and to continue our good hand of writing. Once initiated, writing would then continue by itself through us writing into creation of the world. The rest is history, written by our lives to write us on, world without end quite incorruptible. Such is writing, so stunning, so versatile, so fragile and so creative.

\section{Conflicts of Interest}

The author declares no conflicts of interest regarding the publication of this paper. 


\section{References}

Lin, Y. (1948). The Gay Genius: The Life and Times of Su Tungpo. Melbourne: William Heinemann.

Si, M. C. (2008). Historical Record. Taipei: Sanming Publishers.

Wu, K.-M. (1982). Chuang Tzu: World Philosopher at Play. New York: Crossroad.

Wu, K.-M. (1990). The Butterfly as Companion: Meditations on the First Three Chapters of the Chuang Tzu. Albany: State University of New York Press.

Wu, K.-M. (1997). On Chinese Body Thinking: A Cultural Hermeneutic. Leiden: Brill. 